\title{
Optimism for restoration of refugee health care
}

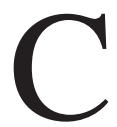

anadian doctors who fought federal cuts to refugee health care are applauding the new government's promise to restore coverage, urging swift action before thousands of Syrian refugees arrive in the country.

"We're more than optimistic," said Dr. Philip Berger of Canadian Doctors for Refugee Care. "We have solid expectations that the health coverage will be fully restored in the way that it was prior to 2012. I think that [John] McCallum is a man of integrity and he will keep his word." (McCallum is the new federal minister of immigration, refugees and citizenship.)

The doctors' group has not spoken to McCallum since the new Liberal government's cabinet was named on Nov. 4, said Berger. "We're grateful to McCallum and the Liberals. We don't want to be pouncing on them," he added.

It is urgent, however, that doctors know of changes soon, before up to 25000 refugees arrive from Syria in need of access to counselling, drug coverage, prostheses, dental coverage and vision care, as well as basic health services, Berger said. The refugees may begin arriving before the end of December.

Privately sponsored refugees and claimants deemed to be from "safe countries," as well as failed refugee claimants, lost access to these baskets of coverage areas when the previous Conservative government changed its Interim Federal Health Program in June 2012. Refugee claimants also lost access to prenatal and emergency care in all but life-threatening circumstances.

Although some health services were later restored after a federal court ruled that the cuts unconstitutional, the coverage remains incomplete. The result is a confusing soup of regulations that leaves medical practitioners unsure of which class of refugees are covered and for which services.

During recent media interviews, McCallum pledged to keep the Liber-

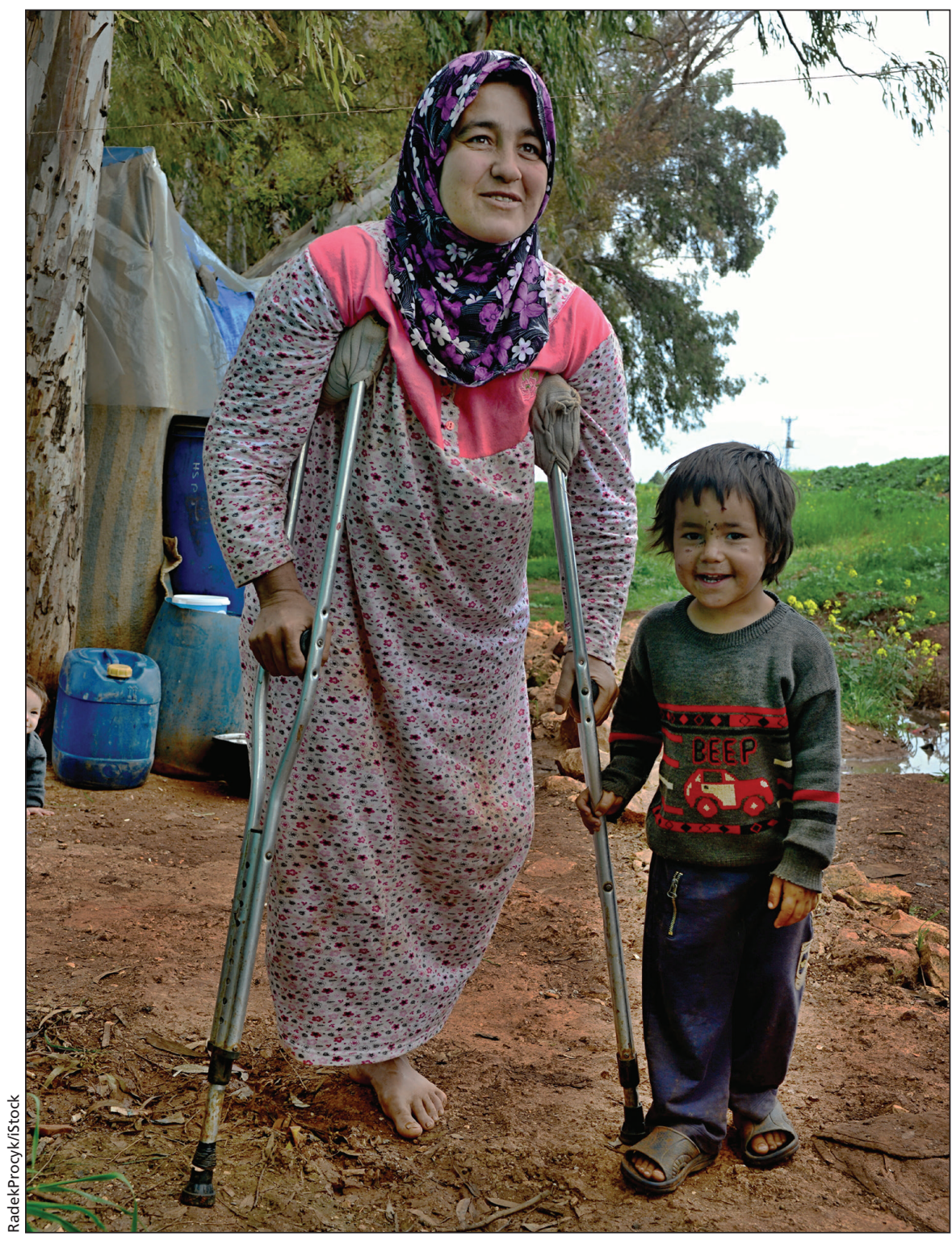

Canada is expecting up to 25000 Syrian refugees and many will need access to health care.

als' campaign promise to reverse the refugee health cuts. He indicated, however, that he must wait until Parliament resumes to deliver on that promise.

But according to Berger, the cuts were made via a cabinet decision, through an order in council, and the new cabinet can issue a counteracting order without waiting for Parliament to resumé. "We don't want to put pressure on them, but it's something that can be done in a matter of days," he said.
Despite the federal court ruling that struck down the Conservative cuts as unconstitutional on the basis of "cruel and unusual" treatment, and the partial restoration of coverage for basic medical services for refugee claimants, many doctors and clinics still don't know if they will be reimbursed for treating refugees, said Dr. Doug Gruner, a family doctor and assistant professor in the University of Ottawa's department of family medicine. 
It's critical that the new government establish and publicize clear, unequivocal rules about coverage for all refugees, doctors say. The paperwork currently involved in submitting claims under the interim program that partially restored coverage is time-consuming and burdensome, Gruner said. Still, he urged walkin clinics to do it.

"These folks barely have enough resources to put food on the table," he said. "This is an extremely vulnerable group and it's not right to expect them to have to pay up front."

In June of this year, Gruner and colleagues surveyed 45 Ottawa walk-in clinics, and of the 43 that responded, only 14 treated refugees without demanding up-front payments of between $\$ 80$ and $\$ 100$, he said. (The survey is not yet published.) Four refused to see refugees and 25 would see them only after receiving payment.

Similar surveys in Toronto and Hamilton also demonstrated the barriers refugees face in obtaining service, Gruner said. When the government does reinstate full coverage, federal officials must spend time and effort to educate physicians, said Berger and Gruner.

"If the government can get this out very publicly that these cuts have been fully completely restored, then really the walk-in clinics should not have any reason not to see refugees as they were doing before the cuts in 2012," Gruner said.

If the government does not act quickly, it will be deferring the costs of required medical treatment to faithbased groups, nongovernmental organizations and individuals privately sponsoring Syrian refugees, said Berger.

The federal government could also signal its intent to restore the cuts by dropping its appeal of the federal court decision. That could also happen "any day" without waiting for Parliament, Gruner pointed out.

"Our expectation is that the government will formally drop the appeal and let the federal court decision stand, which would make it a precedent-setting decision," said Berger. — Laura Eggertson, Ottawa, Ont.

CMAJ 2016. DOI:10.1503/cmaj.109-5196 